\author{
N.K. CHRISTOV ${ }^{1,2}$, S. YONEYAMA ${ }^{1,3}$, \\ Y. SHIMAMOTO ${ }^{3}$, R. IMAI ${ }^{1}$ \\ ${ }^{1}$ Crop Cold Tolerance Research Team, National Agricultural \\ Research Center for Hokkaido Region, Hitsujigaoka 1. \\ Toyohira-ku, Sapporo 062-08555, Japan \\ ${ }_{2}^{2}$ AgroBiolnstitute, Dragan Tsankov 8, Sofia 1164, Bulgaria \\ 1 Laboratory of Plant Genetics and Evolution, Graduate School \\ of Agriculture, Hokkaido University, Sapporo, Japan \\ E-mail: rzi@affec.g.jp
}

\title{
DIFFERENTIAL EXPRESSION OF WHEAT GENES DURING COLD ACCLIMATION
}

\begin{abstract}
Ovenwintering crops such as winter wheat display significant increase in freezing tolerance during a period of cold acclimation (CA). To gain better understanding of molecular mechanisms of $C A$, it is important to unravel functions and regulations of $\mathrm{CA}$-associated genes. Differential screening of a cDNA library constructed from cold acclimated crown tissue of winter wheat identified three novel CA-associated cDNA clones. Nucleotide sequence analysis showed that the clones encode a high mobility globular protein (HMGBI), a glycinerich RNA-binding protein (TaGRP2), and a LEA D-II dehydrin (DHN14). Accumulation of the three $m R N A$ s during 14 days of $C A$ was differentially regulated. In response to drought, and $A B A, D H N 14 m R N A$ rapidly accumulated while HMGBI and TaGRP2 $m R$ NA levels remained unchanged. The possible functions of each of these genes in cold acclimation are discussed.
\end{abstract}

\footnotetext{
C N.K. CHRISTOV. S.YONEYAMA, Y. SHIMAMOTO, R. IMAI, 2007
}

Introduction. Cold acclimation (CA) is the process that allows hardy plants to develop essential tolerance for winter survival through multiple levels of biochemical and cell biological changes $[1,2]$. Dynamic alteration in gene expression occurs during CA process. Reports have identified CA-induced genes from many plant species including winter wheat [2]. Accumulation of some of the cold-induced genes shows positive correlation with the degree of freezing tolerance $[3,4]$. Functions in cold tolerance have been suggested for a number of genes $[5,6]$ (see [7-10] for recent reviews). Previous research has shown that the cytosolic calcium concentration increases after plant exposure to low temperature $[11,12]$ and that $\mathrm{Ca}^{2+}$ modulates low temperature-induced nuclear gene expression [4, 13]. A small family of transcription factors $(C B F 1-3)$, identified in Arabidopsis thaliana, has been shown to activate multiple cold regulated (Cor) genes [14, 15]. The process of $\mathrm{CA}$ appears to require complex and coordinated expression of a whole battery of coldinduced genes. Thus, it is important to increase the number of identified CA-related genes/proteins with determined functions as well as to unravel regulatory mechanisms of $\mathrm{CA}$.

In this paper, we report identification of three novel cDNA clones that accumulate during $\mathrm{CA}$ in wheat crown tissue. Analysis of gene expression during cold, drought and ABA treatments revealed that multiple regulatory pathways are involved in the regulation of CA-related genes.

Materials and Methods. Plant materials and treatments. Winter wheat plants (Triticum aestivum L. cv. Chihoku), used for cDNA library construction and differential screening, were grown under the following condition. Seeds were planted in commercial potting mix, irrigated with tap water, and grown in a growth chamber which is maintained under $22 / 18{ }^{\circ} \mathrm{C}$ (day/night) cycles for $28 \mathrm{~d}$. Control plants were harvested at the end of this period. Cold acclimation was performed by subjecting the plant to $6 / 2{ }^{\circ} \mathrm{C}$ (day/night) cycles for 14 d. Crown tissue was harvested and frozen immediately in liquid nitrogen.

Plants used for stress treatments were grown hydroponically. Surface-sterilized seeds were imbibed in the dark for $12 \mathrm{~h}$ and planted on a plastic mesh grid supported by a container filled with tap water. The container was maintained in a growth chamber at $25{ }^{\circ} \mathrm{C}$ under continuous illumination. After growing for $7 \mathrm{~d}$, wheat seedlings were sub- 
jected to stress treatments. Low temperature, $\mathrm{ABA}$, and dehydration treatments were conducted by transferring the mesh grid to a container with tap water at $4{ }^{\circ} \mathrm{C}, 50 \mu \mathrm{M}$ ABA solution, and without water, respectively.

Construction of $c D N A$ library. Total RNA was isolated from cold-acclimated crown tissue, using TRIzol reagent (Invitrogen, CA, USA) and poly (A) ${ }^{+}$RNA was purified from total RNA using Dynabeads Oligo(dT) 25 (Dynal A.S, Oslo, Norway). cDNA was synthesized with Zap Express cDNA Synthesis Kit and packaged into the phage particles with Gigapack Gold III (Stratagene, CA, USA). A primary cDNA library of $7 \cdot 10^{6}$ plaques was amplified as suggested by the manufacturer's protocol and then used for differential screening.

Differential screening. Total RNA was isolated from non-acclimated (NA) and cold-acclimated (CA) wheat crown tissue, and poly(A) ${ }^{+}$RNA was purified as described above. Double-stranded cDNA was synthesized from poly $(\mathrm{A})^{+} \mathrm{RNA}$, using a oligo-dT primer (Amersham Pharmacia Biotech, NJ, USA). Both cDNAs from NA and CA were labeled with $\left[\alpha-{ }^{32} \mathrm{P}\right] \mathrm{dCTP}$, and used as probes for differential hybridization. Differential hybridization was performed according to the plaque hybridization method [16]. Two copies of plaque blots from the CA cDNA library, covering $5 \cdot 10^{4}$ independent plaques, were hybridized with ${ }^{32} \mathrm{P}$-labeled NA and CA cDNA probes. Hybridization was carried out at $65^{\circ} \mathrm{C}$ with Rapid-Hyb buffer (Amersham Pharmacia Biotech). After overnight hybridization, membranes were washed once with $2 \times \mathrm{SSC}$ and $0.1 \%$ SDS for $15 \mathrm{~min}$ at $65^{\circ} \mathrm{C}$, twice with $0.1 \times$ SSC and $0.1 \%$ SDS for $15 \mathrm{~min}$ at $65^{\circ} \mathrm{C}$. After three rounds of screening, several independent plaques were picked and subjected to in vivo excision using Exassist helper phage (Stratagene) according to the manufacturer's instructions. The excised plasmid DNA was isolated and purified by the alkaline lysis method [16].

Northern blot analysis. Total RNA ( 20 micrograms) was separated in $1.0 \%$ formamide-agarose gel and then transferred onto Hybond- $\mathrm{N}^{+}$membrane (Amersham Pharmacia Biotech) according to standard methods [16]. Rapid-Hyb buffer (Amersham Pharmacia Biotech) containing salmon sperm DNA $(10 \mu \mathrm{g} / \mathrm{ml})$ was used for both prehybridization and hybridization. RNA blots were hybridized with ${ }^{32} \mathrm{P}$-labeled wca 142, wca212, or wca341 full-length cDNA at 65 oC for $16 \mathrm{~h}$. Blots were then washed with $2 \times \mathrm{SSC}$ and $0.1 \%$ SDS for $15 \mathrm{~min}$ and twice with $0.1 \times \mathrm{SSC}$ and $0.1 \%$ SDS for $20 \mathrm{~min}$ at $65^{\circ} \mathrm{C}$ and then exposed to Kodak BioMax MR X-ray film (Kodak, New Haven, CT, USA) with an intensifying screen at $-80^{\circ} \mathrm{C}$.

DNA sequencing analysis. The cloned DNA insert was sequenced by the dideoxy method using Thermo Sequence v2.0 kit (Amersham Pharmacia Biotech) with a DNA sequencer model 373A (Applied Biosystems, San Jose, CA, USA). The sequence databases were searched for sequence similarities at NCBI using the BLAST program. Sequence alignments of the DNA and deduced amino acid sequences were done by ClustalX [17] and visualized using Genedoc software [18].

Results. Cloning of three $c D N A$ clones that are accumulated in cold-acclimated crown. A cDNA library constructed from cold acclimated crown tissue was screened with labeled cDNA from coldacclimated and non-acclimated crown tissues. The differential hybridization identified several clones that are preferentially expressed in coldacclimated crown. Subsequent Northern blot analysis revealed three cDNA clones, designated wca 142, wca 212, and wca341, that were induced in cold-acclimated crown (data not shown). The nucleotide sequencing analysis revealed that wcal42, wca 212, and wca341 encoded a High Mobility Globular (HMG) protein, a glycine-rich RNAbinding protein, and a LEA D-11 dehydrin, respectively.

Structure and function of the encoded proteins. The wcal42 encodes a 161-amino-acid-polypeptide with the predicted molecular size of $17.2 \mathrm{kDa}$. Database searches revealed that the protein encoded by wcal42 showed striking homology with plant $\mathrm{HMGB} 1$ proteins. The identity to barley HvHHMG 12 (CAA90679, [19]) was $92 \%$, followed by $86 \%$ identity to a HMGBI protein from maize (CAA41220; [20], $85 \%$ identity to rice HMGB1 (AAP21609; [21]) and $54 \%$ identity to Arabidopsis HMGB2 (Atlg20693; [22]) (Fig. 1). Therefore we have designated the wheat HMGbox protein as HMGB1. The HMGBI protein consists of the $\mathrm{N}$-terminal domain, the central domain that contains basic DNA-binding regions (so-called HMG-box motifs) and the polyacidic C-terminal region, which is thought to interact with his- 


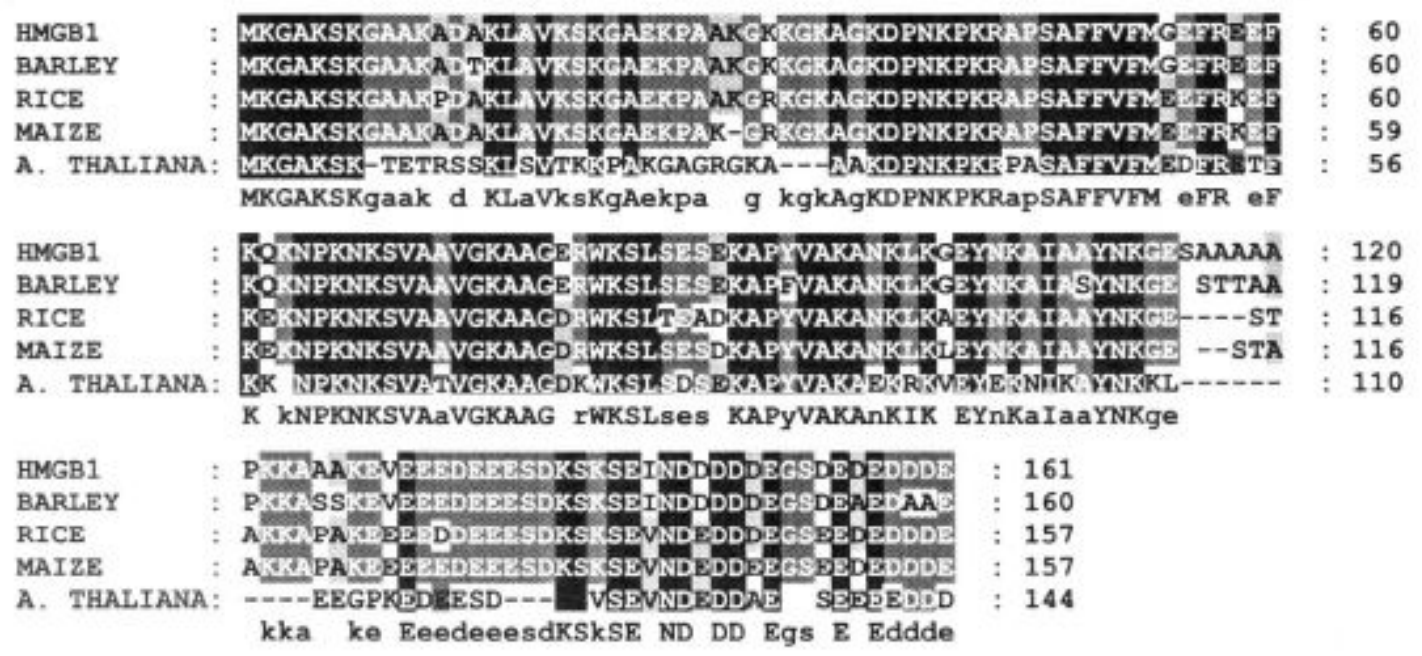

Fig. 1. Multiple alignment of wheat HMGB1 to plant HMG protein sequences. The conserved amino acid residues are shown as white letters on black background while those with partial conservation are shaded in grey. The aligned sequences are Triticum aestivum HMGB1 (AB272226; this study), Hordeum vulgare HVHHMG12 (CAA90679, [19]), Zea mays HMGB1 (CAA4I220; [20]), Oryza sativa (indica) HMGB1 (AAP21609; [21]) and Arabidopsis thaliana HMVB2 (At $\lg 20693 ;[22]$ ). Consensus sequence was indicated in the bottom of the alignment (Cons.). Numbers on the right refer to amino acid position from the $\mathrm{N}$-terminal methionine

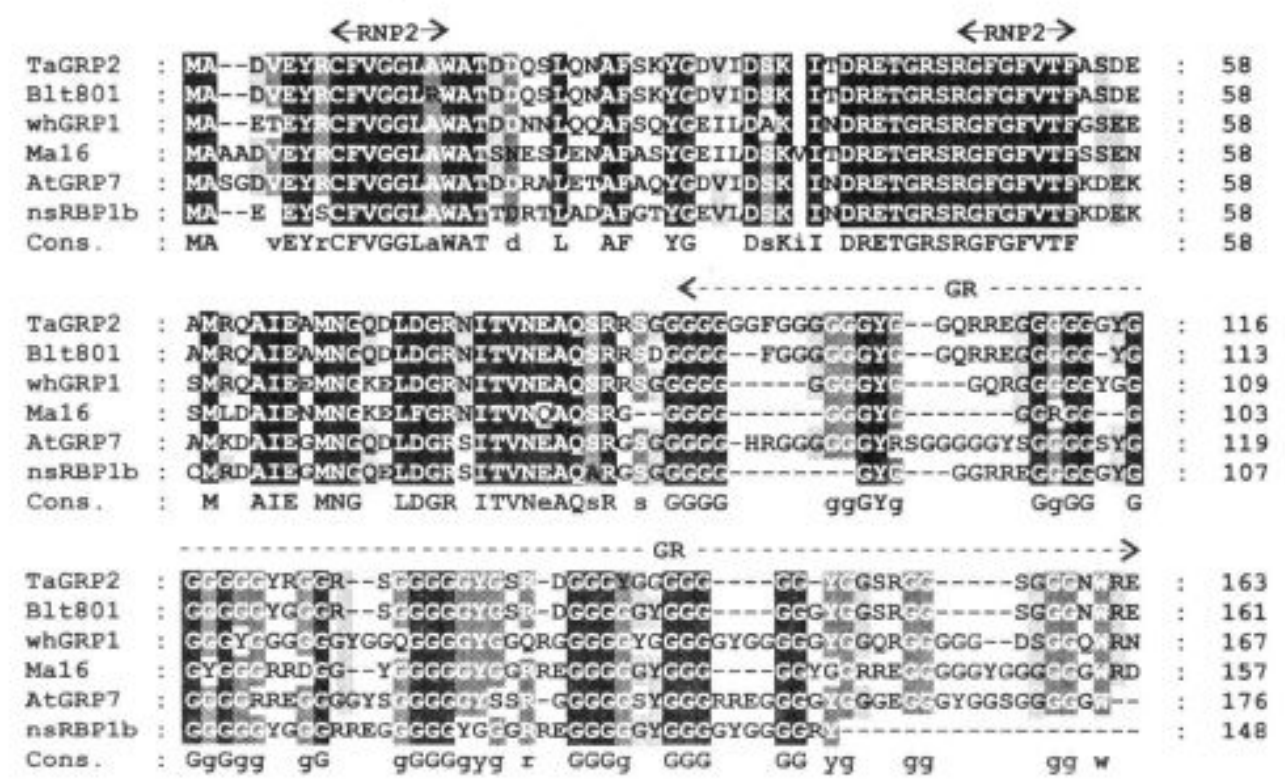

Fig. 2. Multiple alignment of TaGRP2 to plant glycine-rich RNA-binding protein sequences. The RNP1, RNP2 motifs and the Glycine Rich (GR) region are indicated above the sequence. The conserved amino acids are shown as white letters on black background while those with partial conservation are shaded in grey. The aligned sequences are Triticum aestivum TaGRP2 (AB272227; this study), Hordeum vulgare Blt801(AAB07749; Dunn et al., 1996), Triticum aestivum whGRP1 (AAA75104; [25]), Zea mays MA16 (CAA31077; [26]), A. thaliana AtGRP7 (At2g21660; [24]) and N. sylvestris NsRGP1b (BAA03742; [27]). Consensus sequence was indicated in the bottom of the alignment (Cons.). Numbers on the right refer to amino acid position from the $\mathrm{N}$-terminal methionine

tones and may participate in modifying chromatin structure.
The wca212 encodes a 163-amino-acid-polypeptide with the predicted molecular size of $16 \mathrm{kD}$ 


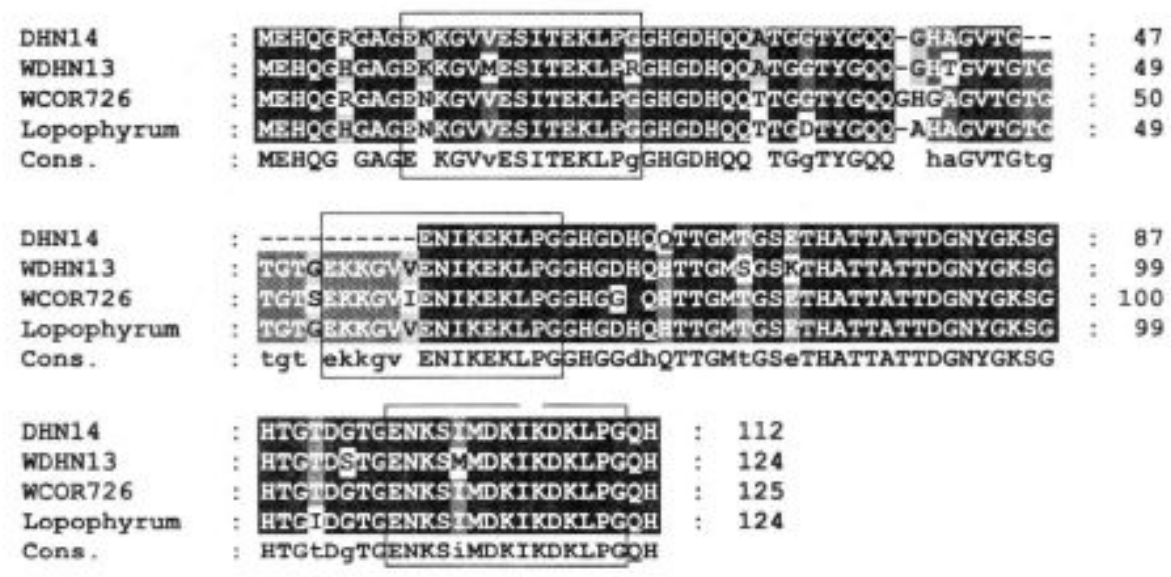

Fig. 3. Multiple alignment of DHN14 to plant dehydrin protein sequences. The conserved amino acids are shown as white letters on black background while those with partial conservation are shaded in grey. The K-segments are boxed. The aligned sequences are Triticum aestivum DHN14 (AB272228; this study), Triticum aestivum WDHN13 (BAC01112; [31]), Triticum aestivum WCOR726 (AAB18204; [29]), and Lophopyrum elongatum (AAC05924; [30]). Consensus sequence was indicated in the bottom of the alignment (Cons.). Numbers on the right refer to amino acid position from the $\mathrm{N}$-terminal methionine

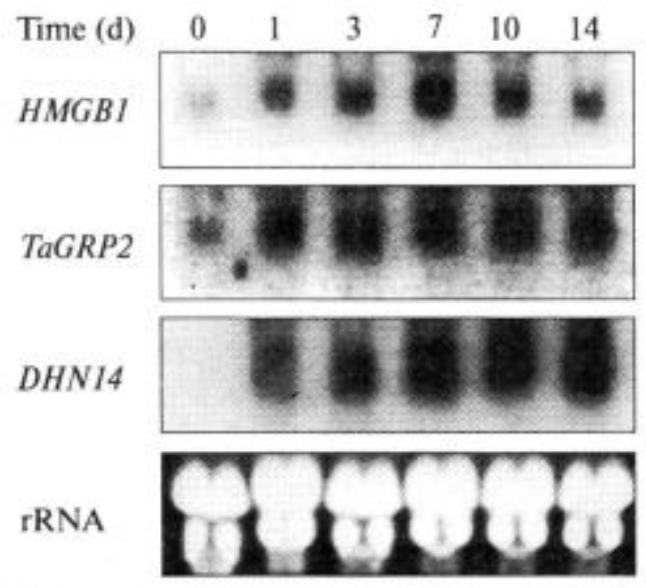

Fig. 4. Expression of HMGB1, TaGRP2 and DHN14 during the course of çold acclimation. 14-day-old plants were subjected to cold acclimation for designated time periods and total RNA $(20 \mu \mathrm{g})$ from the crown tissue was analyzed by Northern blotting analysis. Ethidium bromide-stained gel is shown for a loading control

(TaGRP2) showing high sequence homology to glycine-rich RNA-binding proteins (GR-RBPs) from a number of other plant species. The protein encoded by wca 212 shared $94 \%$ identity with the published barley Blt801(AAB07749; [23]). The identity to other published GR-RBPs was $68 \%$ to $\mathrm{Ara}$ bidopsis AtGRP7 (At2g21660; [24]), $67 \%$ to another wheat GR-RBPs protein, whGRPI (AAA75104, $[25]), 63 \%$ to maize MAI6 (CAA31077; [26]) and $61 \%$ to tobacco $N$. sylvestris NsRGPIb (BAA03742; [27]). Some of the GR-RBPs genes have been reported to increase expression levels in response to environmental stress. All these genes encode protein products with two definitive domains. The amino-terminal domain consists of $80-90$ residues containing two consensus sequences, an octapeptide RNP1 and a hexapeptide RNP2 which are located about 30 amino acids apart (Fig. 2). These consensus sequences together with a number of other highly conserved residues comprise the consensus RNA-binding domain (RRM) found in many RNA-binding proteins localized in the nucleus, cytoplasm and cytoplasmic organelles in plant, animal and fungal cells [28]. The carboxy-terminal domain of plant GR-RBPs consists mainly of repeating glycine residues interspersed with tyrosine and arginine (Fig. 2).

Wca341 encodes an open reading frame of 112 amino acids with a predicted molecular mass of $11.5 \mathrm{kDA}$ thought to be classified to Kn-type LEA D-11 dehydrin family, and consists of two K-segments and an incomplete K-segment. The encoded protein, designated as DHN14, shared $84 \%$ identity with WCOR726 (AAB18204, [29]) and with dehydrin from Lophopyrum elongatum (AAC05924; [30]) while the identity to a recently published wheat dehydrin WDHN13 (BAC01112; [31]), was $83 \%$ (Fig. 3). The DHN14 protein has a 12 -amino-acid-deletion including a part of the second $\mathrm{K}$ segment. The presence of this deletion makes DHN 14 shorter than WCOR726 reported to be the smallest member of WCS120 family [29].

ISSN 0564-3783. Цитология и генетика. 2007. № 3 
Differential accumulation of the HMGB1, TaGRP2 and DHN14 transcripts in response to low temperature. Since the cDNA clones were isolated by a differential screening between NA and CA plant tissues, the expression patterns of HMGB1, TaGRP2 and DHN14 during cold acclimation was determined (Fig. 4). Although an enchanced transcription of all cDNAs was detected within 1 day of CA each of them showed the distinct expression kinetics. In contrast to the other two clones, the mRNA expression of DHN14 could not be detected under the normal growth condition (Fig. 4). The accumulation of both HMGB1 and DHN14 transcripts reached their maximum at 7 days of $\mathrm{CA}$. While expression of $\mathrm{HMGB1}$ slowly declined afterwards up to 14 days of CA, DHN14 expression level remained unchanged. Transcript accumulation of TaGRP2 was almost unchanged after reaching its maximum in 1 day of CA (Fig. 4). To further characterize the cold-induced expression of CAinduced clones, a short time-course expression analysis was carried out using young seedlings. Northern blots showed that induction of TaGRP2 was detectable as soon as in 1 hour of cold treatment in shoots and in 6 hours in root tissues (Fig. 5). In contrast, the detectable expression of DHN 14 was observed only in 6 hours of treatment in both root and shoot tissues but expression in roots was more pronounced. Induction of the HMGBI was somewhat slower. It was detected in 12 hours of cold treatment in roots and in 48 hours in shoots (Fig. 5).

Expression of HMGBI, TaGRP2 and DHN14 in response to dehydration and $A B A$. To determine whether the functions of the wca genes are specifically associated with cold acclimation or more generally with both cold and dehydration stress responses, expression of $H M G B 1, T a G R P 2$ and $D H N 14$ during drought stress was examined by Northern blot analyses with 7-day-old seedlings (Fig. 6). The HMGB1 and TaGRP2 transcripts appeared to be slightly down-regulated by drought treatments in both root and shoot tissues. In contrast, induction of the DHN14 mRNA was detectable in $6 \mathrm{~h}$ and highly accumulated in $24 \mathrm{~h}$ after initiation of the drought treatment (Fig. 6). Involvement of ABA in gene regulation was also examined. Strong induction of $\mathrm{DHN} / 4$ was detectable as early as in $1 \mathrm{~h}$ of $\mathrm{ABA}$ treatment in roots and in $6 \mathrm{~h}$ in shoots, while no induction of HMGB1, TaGRP2 was observed

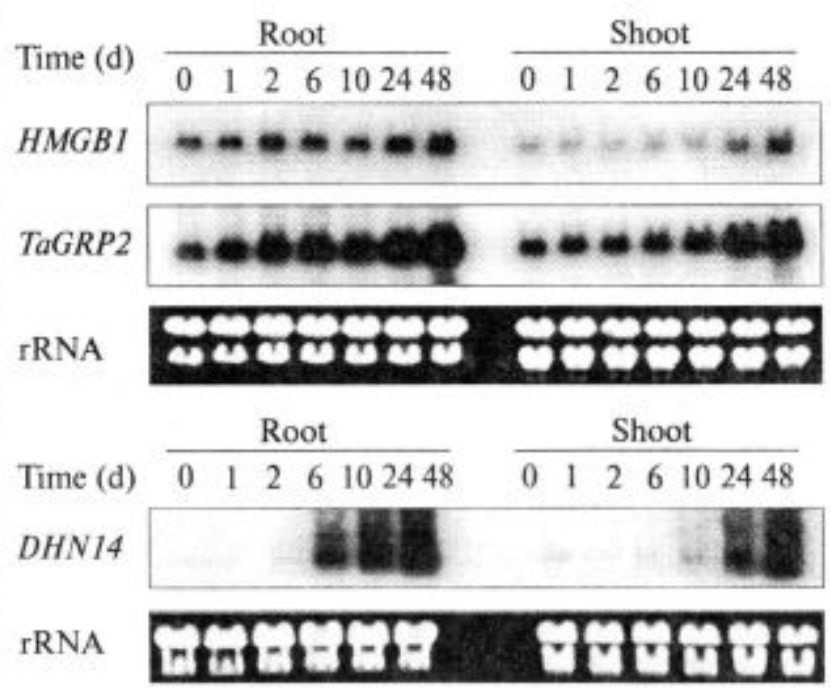

Fig. 5. Expression of HMGB1, TaGRP2 and DHN14 in response to short-term cold stress treatments. Hydroponically grown on plastic mesh grids 7-day-old seedlings were transferred together with the grid into plastic container with cold water $\left(4^{\circ} \mathrm{C}\right)$. At each time point total RNA $(20 \mu \mathrm{g})$ was isolated from shoot and root tissues and analyzed by Northern blot analysis. Ethidium bromide-stained gel is shown for a loading control

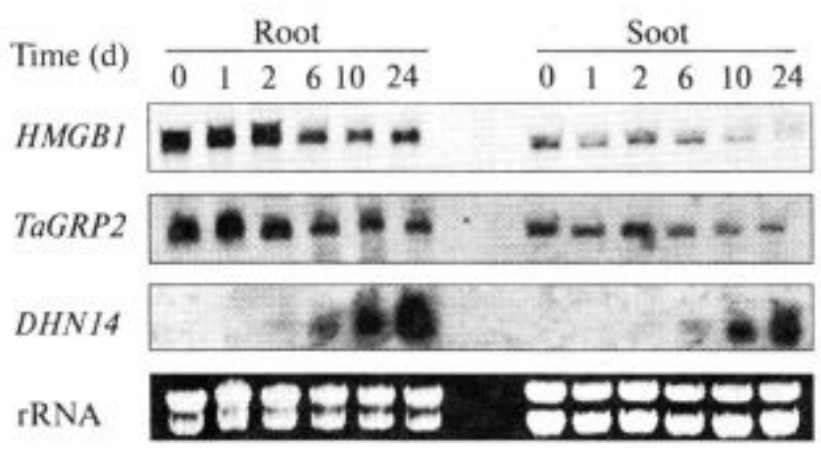

Fig. 6. Expression of HMGB1, TaGRP2 and DHN14 in response to short-term drought stress. Hydroponically grown on plastic mesh grids 7-day-old seedlings were transferred together with the grid into a new plastic container without water. At each time point total RNA $(20 \mu \mathrm{g})$ was isolated from shoot and root tissues and analyzed by Northern blot analysis. Ethidium bromide-stained gel is shown for a loading control

in both root and shoot tissues (Fig. 7). These data suggest that $H M G B I$ and $T a G R P 2$ may have specific functions during cold acclimation, and DHN 14 may act in both cold and dehydration stress responses.

Discussion. In this study we have identified three novel cDNA clones that are up-regulated during 


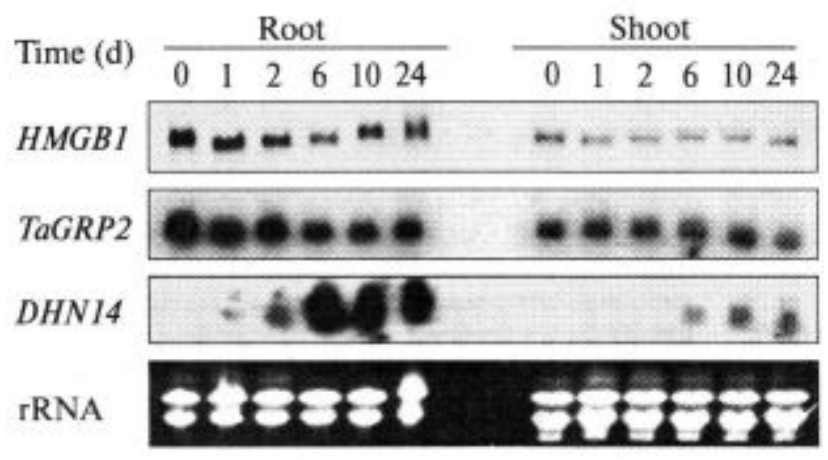

Fig. 7. Expression of HMGB1, TaGRP2 and DHN14 in response to exogenous $\mathrm{ABA}$ treatment. Hydroponically grown on plastic mesh grids 7-day-old seedlings were transferred together with the grid into plastic container with water containing $50 \mu \mathrm{M} \mathrm{ABA}$. At each time point total RNA $(20 \mu \mathrm{g})$ was isolated from shoot and root tissues and analyzed by Northern blot analysis. Ethidium bromidestained gel is shown for a loading control

cold acclimation. According to the sequencing analysis, two of the clones, wca 142 and wca 212 , encode specific proteins thought to be involved in the regulation of gene expression.

The predicted protein encoded by wca 142 had a three-domain structure, highly similar to plant HMGB1 proteins (Fig. 1). Members of the HMG 1 and 2 subgroups (HMGB according to the revised nomenclature [32]) have been variously implicated in DNA replication [33,34], cellular differentiation [35], development [36] and gene expression $[37,38]$. HMG1 directly stimulates in vitro transcription by RNA polymerases II and III [37], and overcomes the inhibition of transcription caused by histones $[37,39]$. The in vitro binding of plant HMG proteins to $\mathrm{A} / \mathrm{T}$-rich regions of doublestranded DNA has also been observed [40-42]. Preferential binding of pea $\mathrm{HMG}$ proteins to a positive regulatory region of the plastocyanin gene promoter has been described [43]. Rice HMGB1 have been demonstrated to bind four-way DNA junctions and efficiently bend DNA [34], thus facilitating binding of transcriptional factors to their target regions. A wheat HMGB protein have been reported to stimulate the binding of the bZIP transcription factor EmBP-1 to the promoter of the ABA responsive Em gene [44]. For a recent review on structure and functions of plant HMG proteins see [45]. Based on Northern and Western blot analyses, the plant $H M G B$ genes are considered to be expressed ubiquitously in the plant [21,
46-48]. On the other hand, there are several reports describing the $\mathrm{HMG}$ gene regulation in mammals. Changes in the levels of HMG transcripts are reported during the development in hatched chick [49], cancer-related increase in mRNA expression in human [50], and circadian rhythm in Pharbitis nil [51]. However this is the first to report that one of the cereal HMGB subgroup protein genes is up-regulated by low temperature.

Taken together, HMGB1 may play a significant role in controlling general aspects of gene expression by modifying chromatin structure, and as such, can be viewed as a higher order regulatory factor. It is possible that the wheat HMGB1 protein functions as a general regulator of gene expression during cold acclimation in wheat.

As there are no reports describing expression of plant HMGB proteins in response to abiotic treatments, we have used Expression Browser through the Botany Array Resource [52] to perform *electronic Northerns of the Arabidopsis HMGB subgroup gene family. The results of eNortherns showed that three out of six Arabidopsis subgroup members, including AtHMGB1, AtHMGB2 and AtHMGB3, were induced by cold treatment and suggested similar functions of some dicot HMGB proteins in the cold regulation of gene expression.

$T a G R P 2$ is a member of a small family representing plant genes encoding proteins with both RNA-binding and glycine-rich (GR) domains, which have been reported to be responsive to various stresses or external stimuli: low temperature and abscisic acid (ABA), Hordeum vulgare [23]; drought and ABA, Zea mays (Ludevid M.D. et al. 1992); wounding, Daucus carota [53]; heavy-metal stress, Zea mays [54]; low temperature and ABA, Brassica napus [55]; low temperature and drought, Arabidopsis thaliana [56]. In addition, transcripts of GR-RBPs from A. thaliana [56] and Sinapis alba [57] have been shown to exhibit a light entrained circadian rhythm, which persists for several cycles upon removal of the light stimulus. The expression patterns of GR-RBPs suggests that glycine-rich proteins represent a class of RNAbinding proteins involved in general molecular responses to environmental stress mediated by post-transcriptional regulatory mechanisms. Three plant GR-RBPs have been experimentally demonstrated to have RNA-binding properties. The 
maize GR protein MA16 [58], tobacco GRP-1b [27] were shown to have in vitro binding preference for homoribopolymers $\mathrm{G}$ and $\mathrm{U}$, and barley BLT801 [23] has affinity for homoribopolymers G, A and U. Putative RNA-binding properties of all other plant GR-RBPs have been deduced by homology. The two-domain organization of plant GR-RBPs is similar to the $\mathrm{A} 1$ and $\mathrm{A} 2 / \mathrm{B} 1$ groups of heterogeneous nuclear RNA-binding proteins ( $h n R N P$ ) found in animals. Although each domain is therefore approximately twice the size of those found in plants. The hnRNPs are associated with nascent hnRNA and are not a part of the other complexes (e.g. snRNA). These proteins are located in the nucleus and have been implicated in pre-mRNA splicing [59]. It has been demonstrated that the GR-RBP from maize, MA16, interacts with a cold inducible DEAD box RNA helicase [60]. Very recently it was found that a DEAD box RNA helicase is essential for mRNA export and import and has important functions in stress responses [61]. The Arabidopsis GR-RBP AtGRP7 was reported to participate in splice site selection and autoregulation of the stability of its own transcript via alternative splicing [62].

The mRNA levels of a large number of genes change during the period of cold acclimation in overwintering cereals [2] and post-transcriptional processes may play crucial roles in the overall control and regulation of eukaryotic gene expression [63]. Therefore, the expression pattern and the sequence similarity of the TaGRP2 protein encoded by wca 212 strongly suggest its involvement in the control of steady-state mRNA levels of low temperature-responsive genes via one of the above mentioned mechanisms.

Expression patterns of $H M G B 1$ and TaGRP2 transcripts were very similar especially at the early stages of cold acclimation suggesting that their transcription during cold acclimation might be triggered and regulated by a common mechanism.

In contrast to its closest homolog wdhn 13 [31], the expression of wca34l was induced by ABA in addition to cold and dehydration treatments, clearly indicating that it is not alternative splicing variant of wdhn 13 but a novel member of the wheat dehydrin family named $\mathrm{DHN} 14$ and showing distinct regulation mechanisms. The accumulation of DHN 14 transcripts in response to ABA treatment started most rapidly, compared to LT and drought stress treatment. This result would indicate that the plant hormone ABA is involved in the regulation of DHN14 transcription caused by LT and drought stresses.

In this study three clones, though all of them were up-regulated by cold treatment, showed distinct expression patterns. The mechanisms of cold regulated gene expression in wheat might be more complicated than expected by the recent studies with the model plants. To better understand molecular events that occur during cold acclimation in cereals, it is important to increase the number of cold acclimation related genes and analyze their function and regulation. It is also important to examine interactions of each protein or signalling pathways involved in cold acclimation.

This work was partially supported by a grant from MAFF (Biodesign, no. 1207) to R.I. and JSPS postdoctoral fellowship to N.K.C. The sequences of HMGB1, TaGRP2 and DHN14, reported in this paper, have been deposited in the DDBJ database (accession no. $A B 272226, A B 272227$ and $A B 272228$ ).

PЕЗЮМЕ. Зимуюшие растения, такие как озимая пшеница, проявляют значительное повышение зимостойкости в период холодовой акклиматизации. Чтобы лучше понять молекулярные механизмы холодовой акклиматизации, важно выявить функшии и регуляцию соответствующих генов. Скрининг библиотеки кДНК тканей корончатых галлов озимой пшенишы, акклиматизированной к холоду, выявил три новых клона кДНК. Анализ нуклеотидной последовательности показал, что клоны кодируют высокомобильный глобулярный белок (HMGB1), богатый глишином РНK-связываюший белок (TaGRP2) и LEA D-11 дегидрин (DHN14). Накопление трех матричных PHK в течение 14 дней холодовой акклиматизации дифференциально регулировалось. В ответ на засуху и обработку абсшизовой кислотой быстро накапливалась MPHK DHN14, в то время как уровни мPHK HMGB1 и TaGRP2 не изменялись. Обсужлается возможная роль каждого из этих генов в холодовой акклиматизации.

PЕЗЮМЕ. Зимуючі рослини, такі як озима пшенишя, проявляють значне підвищення зимостійкості в період холодової акліматизашіі. Щоб краще зрозуміти молекулярні механізми холодової акліматизації, важливо виявити функції і регулящію відповідних генів. Скринінг бібліотеки кДНК тканин корончатих галів озимої пшениці, акліматизованої до холоду, виявив три нових клони кДНК. Аналіз нуклеотидної послідовності показав, що клони кодують високомобіль- 
ний глобулярний білок (HMGB1), багатий гліцином PHK-зв'язувальний білок (TaGRP2) та LEA D-11 дегілрин ((DHN14). Накопичення трьох матричних РНК протягом 14 днів холодової акліматизації диференційно регулювалося. У відповідь на засуху та обробку абсцизовою кислотою швидко накопичувалася мPHK DHN14, в той час як рівні мPHK HMGB1 та TaGRP2 не змінювалися. Обговорюеться можлива роль кожного з цих генів в холодовій акліматизанії.

\section{REFERENCES}

I. Guy C.L. Cold Acclimation and freezing stress tolerance : Role of protein metabolism // Ann. Rev. Plant Physiol. and Plant Mol. Biol. - 1990. - 41. - P. 187223.

2. Pearce R.S. Molecular analysis of acclimation to cold // Plant Growth Reg - 1999. - 29. - P. 47-76.

3. Houde M., Daniel C., Lachapelle M., Allard F., Laliberte $S$., Sarhan F. Immunolocalization of freezing-tolerance-associated proteins in the cytoplasm and nucleoplasm of wheat crown tissues // Plant J. - 1995. - 8. P. 583-593.

4. Monroy A.F., Castonguay Y., Laberge S., Sarhan F, Vezina L.P., Dhindsa R.S. A new cold-induced alfalfa gene is associated with enhanced hardening at subzero temperature // Plant Physiol, - 1993, - 102 - P. 873879.

5. Keresztessy Z., Hughes M.A. Homology modelling and molecular dynamics aided analysis of ligand complexes demonstrates functional properties of lipid-transfer proteins encoded by the barley low-temperature-inducible gene family, blt4 // Plant J, - 1998. - 14. P. 523-533.

6. Uemura M., Gilmour S.J., Thomashow M.F., Steponkus P.L. Effects of COR6.6 and COR15am polypeptides encoded by COR (cold-regulated) genes of Arabidopsis thaliana on the freeze-induced fusion and leakage of liposomes // Plant Physiol. - 1996. - 111. - P. 313-327.

7. Chinnusamy V., Zhu J., Zhu J.K. Gene regulation during cold acclimation in plants // Physiol. Plant. 2006. - 126. - P. 52-61.

8. Pragya Sharma NSRD. The molecular biology of the low-temperature response in plants // BioEssays. 2005. - 27. - P. 1048-1059.

9. Thomashow M.F. Role of Cold-responsive genes in plant freezing tolerance // Plant Physiol. - 1998. 118. - P. $1-8$.

10. Zhang J.Z., Creelman R.A., Zhu J.-K. From laboratory to field. Using information from Arabidopsis to engineer salt, cold, and drought tolerance in Crops // Plant Physiol. - 2004. - 135. - P. 615-621.

11. Knight H., Trewavas A.J., Knight M.R. Calcium signalling in Arabidopsis thaliana responding to drought and salinity // Plant J. - 1997. - 12. - P. 10671078 .
12. Plieth $C$. Temperature sensing by plants: calcium-permeable channels as primary sensors - a model // J. Membr. Biol. - 1999, - 172. - P. 121-127.

13. Monroy A.F., Dhindsa R.S. Low-temperature signal transduction: induction of cold acclimation-specific genes of alfalfa by calcium at 25 degrees C // Plant Cell. - 1995. - 7. - P. 321-331.

14. Jaglo-Ottosen K.R., Gilmour S.J., Zarka D.G., Schabenberger O., Thomashow M.F. Arabidopsis CBFI overexpression induces COR genes and enhances freezing tolerance // Science. - 1998. - 280. - P. 104106.

15. Liu Q., Kasuga M., Sakuma Y., Abe H., Miura S., Yamaguchi-Shinozaki K., Shinozaki $K$. Two transcription factors, DREB1 and DREB2, with an EREBP/AP2 DNA binding domain separate two cellular signal transduction pathways in drought- and low-temperature-responsive gene expression, respectively, in Arabidopsis // Plant Cell. - 1998. - 10. - P. 1391-1406.

16. Sambrook J., Fritsch E.F., Maniatis T. Molecular cloning : A laboraty manual. - Cold Spring Harbor Laboratory Press, 1989.

17. Chenna R., Sugawara H., Koike T., Lopez R., Gibson T.J., Higgins D.G., Thompson J.D. Multiple sequence alignment with the Clustal series of programs // Nucl. Acids Res. - 2003. - 31. - P. 3497-3500.

18. Nicholas K.B., Nicholas Jr. H.B., Deerfield D.W. GeneDoc: analysis and visualization of genetic variation // EMBNEW. NEWS 4, 1997, - 14.

19. Hess W.R., Boener T. Molecular Cloning of a DNA-binding protein from barley related to maize MNBIb and HMGa // Endocytobiosis and Cell Res. - 1997, - 12. - P. 95-98.

20. Grasser K.D., Feix G. Isolation and characterization of maize cDNAs encoding a high mobility group protein displaying a HMG-box // Nucl. Acids, Res, - 1991. 19. - P. 2573-2577.

21. Wu Q., Zhang W., Pwee K.H., Kumar P.P. Cloning and characterization of rice HMGB1 gene // Gene, 2003. - 312. - P. 103-109.

22. Stemmer C., Ritt C., Igloi G.L., Grimm R., Grasser K.D. Variability in Arabidopsis thaliana chromosomal highmobility-group-1-like proteins// Eur. J. Biochem. 1997. - 250. - P. 646-652.

23. Dunn M.A., Brown K., Lightowlers R., Hughes M.A. A low-temperature-responsive gene from barley encodes a protein with single-stranded nucleic acid-binding activity which is phosphorylated in vitro // Plant Mol. Biol. - 1996. - 30. - P. 947-959.

24. Nocker S. van, Vierstra R.D. Two cDNAs from Arabidopsis thaliana encode putative RNA binding proteins containing glycine-rich domains // Plant Mol. Biol. 1993, - 21. - P. 695-699.

25. Guiltinan M.J., Niu X. cDNA encoding a wheat (Triticum aestivum cv. Chinese spring) glycine-rich RNA- 
binding protein // Plant Mol. Biol. - 1996. - 30. P. $1301-1306$.

26. Gomez J., Sanchez-Martinez D., Stiefel V., Rigau J., Puigdomenech $P$., Pages $M$. A gene induced by the plant hormone abscisic acid in response to water stress encodes a glycine-rich protein // Nature. - 1988. - 334. - P. 262.

27. Hirose T., Sugita M., Sugiura M. cDNA structure, expression and nucleic acid-binding properties of three RNA-binding proteins in tobacco: occurrence of tissue-specific alternative splicing // Nucl. Acids. Res. 1993. - 21 - P. 3981-3987.

28. Alba M., Pages $M$. Plant proteins containing the RNArecognition motif // Trends Plant Sci. - 1998. - 3. P. $15-21$.

29. Danyluk J., Perron A., Houde M., Limin A., Fowler B., Benhamou N., Sarhan F. Accumulation of an acidic dehydrin in the vicinity of the plasma membrane during cold acclimation of wheat // Plant Cell. - 1998. 10. - P. 623-638.

30. Galvez A.F., Gulick P.J., Dvorak J. Characterization of the early stages of genetic salt-stress responses in salttolerant Lophopyrum elongatum, salt-sensitive wheat, and their amphiploid // Plant Physiol. - 1993. - 103. P. $257-265$.

31. Ohno R., Takumi S., Nakamura C. Kinetics of transcript and protein accumulation of a low-molecularweight wheat LEA D-11 dehydrin in response to low temperature // J. Plant Physiol. - 2003, - 160. P. 193-200.

32. Bustin $M$. Revised nomenclature for high mobility group (HMG) chromosomal proteins // Trends Biochem. Sci. - 2001. - 26. - P. 152-153.

33. Alexandrova E.A., Beltchev B.G. Acetylated HMGI protein interacts specifically with homologous DNA polymerase alpha in vitro // Biochem. Biophys. Res. Communs. - 1988. - 154. - P. 918-927.

34. Bonne-Andrea C., Harper F., Sobczak J., De Recondo A.M. Rat liver HMG1: a physiological nucleosome assembly factor // EMBO J. - 1984. - 3. - P. 1193-1199.

35. Crippa M.P., Nickol J.M., Bustin M. Differentiationdependent alteration in the chromatin structure of chromosomal protein HMG-17 gene during erythropoiesis // J. Mol. Biol. - 1991. - 217, - P. 75-84.

36. Lichota J., Ritt C., Grasser K.D. Ectopic expression of the maize chromosomal HMGB1 protein causes defects in root development of tobacco seedlings // Biochem. Biophys. Res. Communs. - 2004 - 318. - P. 317-322.

37. Tremethick D.J., Molloy P.L. High mobility group proteins 1 and 2 stimulate transcription in vitro by RNA polymerases II and III // J. Biol. Chem. - 1986. 261. - P. 6986-6992.

38. Tremethick D.J., Molloy P.L. Effects of high mobility group proteins 1 and 2 on initiation and elongation of specific transcription by RNA polymerase II in vitro // Nucl. Acids. Res, - 1988. - 16. - P. 11107-11123.
39. Kohlstaedt L.A., Sung E.C., Fujishige A., Cole R.D. Nonhistone chromosomal protein $\mathrm{HMG} 1$ modulates the histone $\mathrm{H} 1$-induced condensation of DNA // J. Biol. Chem. - 1987. - 262. - P. 524-526.

40. Jacobsen K., Laursen N.B., Jensen E.O., Marcker A., Poulsen C., Marcker K.A. HMG I-like proteins from leaf and nodule nuclei interact with different AT motifs in soybean nodulin promoters // Plant Cell. - 1990. 2. - P. 85-94.

41. Maier U.G., Grasser K.D., Haass M.M., Feix G. Multiple proteins bind to the $\mathrm{P} 2$ promoter region of the zein gene pMS1 of maize // Mol. Gen. Genet. - 1990. 221. - P. 164-170.

42. Pedersen T.J., Arwood L.J., Spiker S., Guiltinan M.J., Thompson W.F. High mobility group chromosomal proteins bind to AT-rich tracts flanking plant genes // Plant Mol. Biol. - 1991. - 16. - P. 95-104.

43. Webster C.I., Packman L.C., Gray J.C. HMG-1 enhances $\mathrm{HMG}-\mathrm{I} / \mathrm{Y}$ binding to an $\mathrm{A} / \mathrm{T}$-rich enhancer element from the pea plastocyanin gene // Eur. J. Biochem. - 2001. - 268. - P. 3154-3162.

44. Schultz T.F., Spiker S., Quatrano R.S. Histone H1 enhances the DNA binding activity of the transcription factor EmBP-1 // J. Biol. Chem. - 1996. - 271. P. $25742-25745$.

45. Grasser K.D. Chromatin-associated HMGA and HMGB proteins: versatile co-regulators of DNA-dependent processes // Plant Mol. Biol. - 2003. - 53. - P. 281-295.

46. O'Neill S. D., Zheng C.C. Abundance of mRNAs encoding $\mathrm{HMG} 1 / \mathrm{HMG} 2$ class high-mobility-group DNAbinding proteins are differentially regulated in cotyledons of Pharbitis nil // Plant Mol. Biol. - 1998. - 37. P. 235-241.

47. Stemmer C., Grimm R., Grasser K.D, Occurrence of five different chromosomal HMG1 proteins in various maize tissues // Plant Mol. Biol. - 1999. - 41. - P. 351-361.

48. Yamamoto $S$., Minamikawa $T$. Isolation and characterization of a cDNA encoding a high mobility group protein HMG-I from Canavalia gladiata D.C. // Biochim. Biophys. Acta. - 1998, - 1396. - P. 47-50.

49. Oka T., Endo Y., Ito M., Miyamoto K., Sasakawa T., Suzuki I., Natori $Y$. Molecular cloning of chick liver HMG 2a cDNA and developmental expression of HMG 2a mRNA // Biochim. Biophys. Acta. - 1992. - 1130. P. 224-226.

50. Xiang Y.Y., Wang D. Y., Tanaka M., Suzuki M., Kiyokawa E., Igarashi H., Naito Y., Shen Q., Sugimura H. Expression of high-mobility group-1 mrna in human gastrointestinal adenocarcinoma and corresponding non-cancerous mucosa // J. Cancer (Pred. Oncol.). 1997. - 74. - P. 1-6.

51. Zheng C.C., Bui A.Q., O'Neill S.D. Abundance of an mRNA encoding a high mobility group DNA-binding protein is regulated by light and an endogenous rhythm // Plant Mol. Biol. - 1993, - 23. - P. 813-823. 
52. Toufighi K., Brady S.M., Austin R., Ly E., Provart N.J. Technical advance : The botany array resource: e-northerns, expression angling, and promoter analyses // Plant J. - 2005, - 43. - P. 153.

53. Sturm N.R., Maslov D.A., Blum B., Simpson L. Generation of unexpected editing patterns in Leishmania tarentolae mitochondrial mRNAs: misediting produced by misguiding // Cell. - 1992. - 70. - P. 469-476.

54. Didierjean L., Frendo P., Burkard $G$. Stress responses in maize : Sequence analysis of cDNAs encoding glycinerich proteins // Plant Mol. Biol. - 1992. - 18. - P. 847849.

55. Bandziulis R.J., Swanson M.S., Dreyfuss G. RNA-binding proteins as developmental regulators // Genes Dev. 1989. - 3. - P. 431-437.

56. Carpenter C.D., Kreps J.A., Simon A.E. Genes encoding glycine-rich Arabidopsis thaliana proteins with RNAbinding motifs are influenced by cold treatment and an endogenous circadian rhythm // Plant Physiol. 1994. - 104. - P. 1015-1025.

57. Heintzen C., Melzer S., Fischer R., Kappeler S., Apel K., Staiger D. A light- and temperature-entrained circadian clock controls expression of transcripts encoding nuclear proteins with homology to RNA-binding proteins in meristematic tissue // Plant J. - 1994. - 5. P. $799-813$.

58. Ludevid M.D., Freire M.A., Gomez J., Burd C.G., Albericio $F$., Giralt $E$., Dreyfuss $G$., Pages $M$. RNA binding characteristics of a $16 \mathrm{kDa}$ glycine-rich protein from maize // Plant J. - 1992. - 2. - P. 999-1003.
59. Dreyfuss G., Swanson M.S., Pinol-Roma S. Heterogeneous nuclear ribonucleoprotein particles and the pathway of mRNA formation // Trends Biochem. Sci. 1988, - 13. - P. 86-91.

60. Gendra E., Moreno A., Alba M.M., Pages M. Interaction of the plant glycine-rich RNA-binding protein MA16 with a novel nucleolar DEAD box RNA helicase protein from Zea mays // Plant J. - 2004. - 38. - P. 875-886.

61. Gong Z, Dong C.-H., Lee H., Zhu J., Xiong L., Gong D., Stevenson B., Zhu J.-K. A DEAD Box RNA helicase is essential for mRNA export and important for development and stress responses in Arabidopsis // Plant Cell. - 2005. - 17. - P. 256-267.

62. Staiger D., Zecca L., Wieczorek Kirk. D.A., Apel K., Eckstein $L$. The circadian clock regulated RNA-binding protein AtGRP7 autoregulates its expression by influencing alternative splicing of its own pre-mRNA // Plant J. - 2003, - 33, - P. 361-371.

63. Siomi $H$., Dreyfuss $G$. RNA-binding proteins as regulators of gene expression // Curr. Opin. Genet. Dev. 1997. - 7. - P. 345-353.

Received 13.09.06

\section{ABBREVIATIONS}

$\mathrm{CA} \quad$ - cold acclimation

NA $\quad-$ non-acclimation

DA - de-acclimation

HMG protein - high mobility globular protein

GR-RBP - glycine-rich RNA binding protein

ABA $\quad-$ abscisic acid. 